\title{
DETERMINATION OF STRUCTURAL ELEMENTS INTENDED TO RESISTANCE AGAINST EARTQUAKE AND RENEWABLE ENERGY USAGE
}

\author{
Ing. Poyraz Kağan, Ph.D.; doc. Ing. Kulhánek František, CSc.
}

\begin{abstract}
The primary aim of office buildings is to provide a working environment with innovative solutions for the inclusion of needs of all positions including administrative and managerial workers. While offices can be appearing in almost any building; requirements complicate the construction. These requirements can be due to legal regulations, and technical needs. This study focuses on combined solutions via determination and preliminary calculation of structural components intended to resistance against earthquake and usage of possible renewable energy sources. The project building consists of 10 floors by way of application of reinforced concrete in conjunction with convenient application of heating, ventilating, and air conditioning (HVAC) systems, PV installation, high level of solar gain and interchangeable design. Static calculations are based on Turkish standards as Turkey is located over large seismic zone.
\end{abstract}

Key words: sustainable design, office building, earthquake resistance, beamless slab design

\section{INTRODUCTION}

The basic philosophy of the study is to provide suitable model which answers to needs as combination of earthquake resistance and renewable energy usage. Founds are supported with example designs of the case project building which is located in Ankara. In this context, the workout starts with designation of functional and technological requirements where convenient solutions match for environmental susceptibility, energy efficiency, minimized maintenance cost and seismic design. To fulfil the other needed requirements such as flexibility of occupation, daylight, principal planning dimensions, access to the building, car parking, fire precautions, design energy targets, security, soft landscaping, external hard landscaping, building acoustics, issues for disable users (general, external access, building approach, entrance, internal layout, lifts), main areas and reception areas, main circulation, open plan offices, stores, staff toilets, tea points, kitchens and lift subjects were also considered and applied for architectural and static drawings.

The building has beamless reinforced concrete load bearing system which provides easy implementation HVAC systems with open space creation (Poyraz 2015, s. 82).

Big part of Turkey's urban household live in midrise dwelling houses. Typical skeleton system is used for such type apartments. Mainly valid two designs are skeleton system (concrete columns and beams) and formwork system (mostly high buildings). Buildings are typically separate and do not share common walls with adjacent buildings which are very different than European buildings. Most of them have rectangular shape.

Based on the general construction trend research for the case location, it has been assessed that reinforced concrete construction is the optimum in terms of application experience and material procurement. The project building has beamless frame reinforced concrete construction load bearing (mushroom slab) system. For instance, timber is not selected for the load bearing material due to number of floors and length of the span. Due to bigger cross section areas are needed and timber 
structures are not suitable for earthquake effect. It does not have enough strength for high buildings which are in earthquake region. Elasticity module of timber is very low compared to elasticity module of concrete. Thence, low elasticity module of the wood in the timber structures leads to greater deflection.

Curtain wall option for facade provides maximum solar gain. However, to prevent thermal mass or risk of overheating, blind system must be included for shadowing. Usage of curtain wall system at open space building should work as light pipe installation. Flat roof is convenient for installation of PV panels; installed PV panels should be oriented to south direction with 32 degrees for inclinations [1]. Window arrangement that optimizes internal needs, provides highest natural lightening and ideally usage of sun light is a factor, effects envelope of a building [2]. Day lighting arrangements in normal offices should provide for an average daylight factor of not less than $1.8 \%$ [3].

\section{GENERAL STRUCTURAL NOTES}

Load bearing structural elements' dimension calculation and preliminary check of the sizes are according to TS 500 [4] and regulation of construction for buildings in seismic zones ${ }^{1}$ (DBYYHY 2007) [5]. Calculations for columns are made by dividing the building to 3 regions with aim of saving material, and money. By this step, we reduce size of columns. The chosen concrete class is C40. The columns have head to resist for punching effect. Shear walls are located as core system. Eccentricity of shear walls is under limit condition which is $10 \%$ of for both $\mathrm{x}$ and $\mathrm{y}$ directions [6]. Because the force produced by earthquake pass from the core of buildings. The building has mat type foundation as it is convenient for soil type in the location of the building and also for building weight simultaneously. The detailed project is also computed with SAP 2000 software.
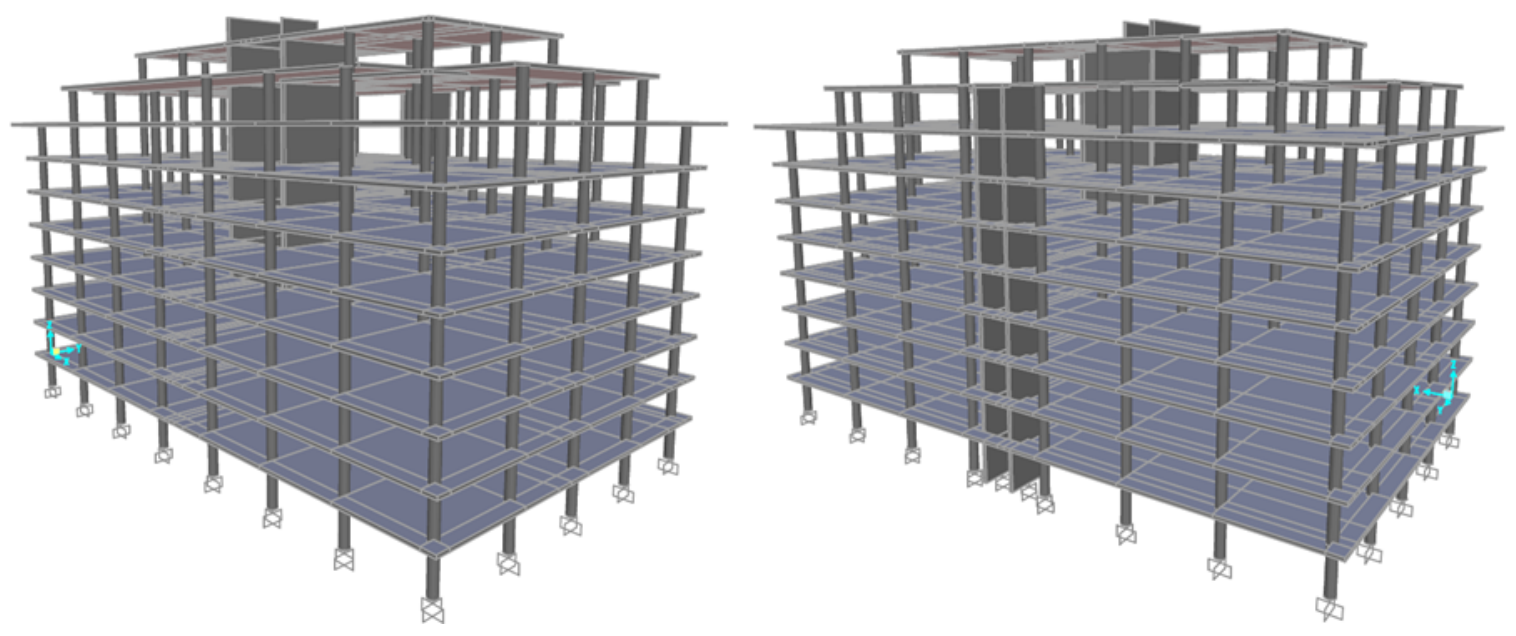

Fig. 1 Perspective of the case project building - SAP 2000 [7]

Due to speed of production and minimize cost, staircases are elements of precast production. Within aims such as minimized maintenance and service, durability, recyclable material usage and effective solar gain; surface of the building designed as glass curtain wall. There are three levels of numbered headers. Thermal characteristics of the building are calculated via İzoder software which bases on TS 825 [8]. Heat and condensation situations are analyzed in detail by arranging the convenient layer.

\footnotetext{
${ }^{1}$ Name of the source is translated by the author. Original name of the regulation is "Deprem Bölgelerinde Yapılacak Binalar Hakkında Yönetmelik 2007”.
} 


\section{PRELIMINARY CALCULATIONS OF STRUCTURAL ELEMENTS}

\subsection{Slab and Column}

\begin{tabular}{|c|c|c|}
\hline Structural Element & Design Formula & Explanation \\
\hline Slab & $\mathrm{h} \geq \frac{\mathrm{l}_{1}}{30}$ and $\mathrm{h} \geq 200 \mathrm{~mm}$ & $\mathrm{~L}_{1}: 7.500 \mathrm{~mm} ; \mathrm{h} \geq \frac{7.500}{30}=250 \mathrm{~mm}$ \\
\hline Column & $\begin{array}{l}\mathrm{d} \leq 0,4 \times \mathrm{l}_{1} ; \mathrm{c} \geq 300 \mathrm{~mm} \\
\mathrm{c} \geq \mathrm{l}_{1} / 20 ; \mathrm{r} \leq 1_{1} / 10 \\
\min _{\mathrm{c}}=\frac{\mathrm{N}_{\mathrm{d}}}{0,5 \mathrm{xf}_{\mathrm{ck}}}\end{array}$ & $\begin{array}{l}\text { All columns have circular shape. Columns' } \\
\text { heads are necessary for punching effect. } \\
\leq 0,4 \times 7.500 \mathrm{~mm}=3.000 \mathrm{~mm} \text { and } \\
7.500 / 10=750 \mathrm{~mm}\end{array}$ \\
\hline
\end{tabular}

Tab. 1 Key formulas and notes for slab, and column design [4]

\begin{tabular}{|c|c|c|c|c|c|c|}
\hline Floor & $\begin{array}{l}\text { Load per } \\
\text { Floor }\left[t / \mathbf{m}^{2}\right]\end{array}$ & $\begin{array}{l}\text { Total } \\
\text { Load }[t]\end{array}$ & $\begin{array}{l}\text { Required } \\
\text { Area }\left[\mathrm{m}^{2}\right]\end{array}$ & $\begin{array}{l}\text { Estimated } \\
\text { Area }\left[\mathrm{m}^{2}\right]\end{array}$ & $\begin{array}{l}\text { Design Diameter } \\
\text { of Column [mm] }\end{array}$ & Load Case \\
\hline $0-3$ & 40,552 & 380,948 & 0,1904 & 0,1963 & 750 & \multirow{3}{*}{$\begin{array}{l}1,4 \times \mathrm{g}+1,6 \times \mathrm{q} \\
\mathrm{g} \text { : dead load. } \\
\mathrm{q} \text { : variable load. }\end{array}$} \\
\hline $3-6$ & 40,552 & 252,624 & 0,1263 & 0,1590 & 450 & \\
\hline $6-10$ & 40,552 & 125,376 & 0,0626 & 0,0478 & 300 & \\
\hline
\end{tabular}

Tab. 2 Design results of a column $(\mathrm{CO1})$

\subsection{Shear Wall}

A shear wall can be defined as a component that lateral sizes are minimally seven or more times bigger than crossed one. According to DBYBHY 2007, smaller size of the shear wall cannot be less than $200 \mathrm{~mm}$ or $1 / 20$ times of the storey height. Example shear wall: Weight $(\mathrm{B})=25 \mathrm{~cm}$ and length $(\mathrm{L})=395 \mathrm{~cm} ; \mathrm{B} / \mathrm{L}=395 / 25=15,8>7$ that fulfils the minimal size rate condition.

A building located in a seismic zone must have sufficient number of shear wall to resist the horizontal forces in perpendicular angle [6]. ${ }^{2}$

$$
\mathrm{A}_{\mathrm{sw}} \geq 0,0015 \times \mathrm{n} \times \mathrm{A}_{\mathrm{f}} \text { and } \mathrm{A}_{\mathrm{sw}} / \mathrm{A}_{\mathrm{f}} \geq 0,008
$$

The main mission of these components is to increase the torsional rigidity of a structure. In this sense, the more shear wall, the more torsional rigidity. Also that closer location to exterior frame means more proper design. Shear walls should be located symmetrically and eccentricity centre of shear walls should not be out of centre of mass of building more than $10 \%$ on both direction perpendicular to each other (mostly defined such as $\mathrm{x}$ and $\mathrm{y}$ directions). ${ }^{2}$

$$
\text { Ideal: } \mathrm{e}_{\mathrm{x}}=\mathrm{e}_{\mathrm{y}}=0 \text { and acceptable: } \mathrm{e}_{\mathrm{x}}, \mathrm{e}_{\mathrm{y}}<10 \%
$$

From the point of structural design, stiffness and mass centre should coincide with central way and position of shear walls should be symmetric. Load bearing concrete walls have largest horizontal resistant force, support resistance the migration of the structure difficult members [9].

\footnotetext{
${ }^{2}$ Explanation for the abbreviations: $\mathbf{A}_{\mathbf{c}}-$ Cross section area of column; $\mathbf{h}$ - Thickness of slab; $\mathbf{d}$-Diameter of column head; $\mathbf{r}$ - Radius of column head; $\mathbf{c}$ - Diameter of column; $\mathbf{l}_{\mathbf{l}}$ - The longest distance of slab between supports; $\mathbf{N}_{\mathbf{d}}-$ Transferred design load; $\mathbf{f}_{\text {ck }}-$ Characteristic pressure strength of concrete; $\mathbf{f}_{\mathbf{c d}}-$ Design pressure strength of concrete; $\mathbf{A}_{\mathbf{s w}}-$ Total cross section area of shear walls (one direction); $\mathbf{n}$ - Number of floor; $\mathbf{A}_{\mathbf{f}}-$ Floor area (in the case of different floor areas; biggest floor area is used); $\mathbf{e}_{\mathbf{x}}-$ Eccentricity on $\mathrm{x}$ direction; $\mathbf{e}_{\mathbf{y}}-$ Eccentricity on y direction.
} 


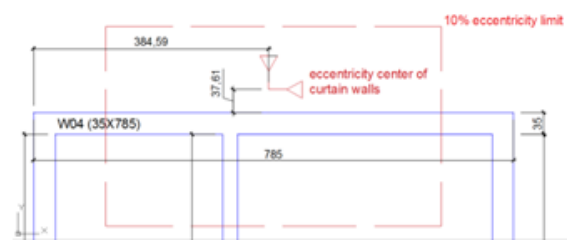

Fig. 2 Eccentricity diagram of shear walls (case project)

\subsection{Foundation}

The selected and preliminary designed foundation type is cast in place mat foundation. In this context, thickness of the foundation is check by the punching control through transferred the biggest load. According to TS 500, foundation thickness cannot be less than $200 \mathrm{~mm}$, and additionally; the minimum foundation thickness is $300 \mathrm{~mm}$ with respect to DBYBHY 2007. Further details related with the calculation are presented below:

- $\quad$ Bearing capacity of the soil $\left[\mathrm{t} / \mathrm{m}^{2}\right]: 7$

- $\quad$ Ductility level: Normal

- $\quad$ Effective ground acceleration coefficient $\left(\mathrm{A}_{\circ}\right): 0,10$ (4 ${ }^{\text {th }}$ earthquake zone)

- $\quad$ Building importance factor (I): 1

- $\quad$ Load bearing system behaviour coefficient: 4

\begin{tabular}{|l|l|l|l|l|l|}
\hline $\begin{array}{l}\text { Total Load Bearing } \\
\text { Area }\left[\mathrm{m}^{2}\right]\end{array}$ & Load $[\mathrm{t}]$ & $\begin{array}{l}\text { Total } \\
\text { Weight }[\mathrm{t}]\end{array}$ & $\mathrm{N}_{\mathrm{d}}[\mathrm{t}]$ & $\begin{array}{l}\text { Total } \\
\text { Area }\left[\mathrm{m}^{2}\right]\end{array}$ & $\begin{array}{l}\sigma_{\mathrm{z}} \\
{\left[\mathrm{t} / \mathrm{m}^{2}\right]}\end{array}$ \\
\hline 253 & 418,715 & 870 & $12.141,590$ & $1.948,24$ & 6,23208125 \\
\hline
\end{tabular}

Tab. 3 Physical features of shear walls and check of foundation thickness via load bearing capacity of soil ${ }^{3}$

\begin{tabular}{|l|l|l|l|l|l|}
\hline $\mathbf{h}[\mathbf{m}]$ & $\mathbf{d}[\mathbf{m}]$ & $\mathbf{A}_{\mathbf{p}}\left[\mathbf{m}^{2}\right]$ & $\mathbf{U}_{\mathbf{p}}[\mathbf{m}]$ & $\mathbf{V}_{\mathbf{p d}}[\mathbf{t}]$ & $\mathbf{V}_{\mathbf{p r}}[\mathbf{t}]$ \\
\hline 1,15 & 1,1 & 2,984513021 & 5,969026042 & 950,111276 & 971,7574396 \\
\hline
\end{tabular}

Tab. 4 Physical features of the designed foundation and shear/punching forces situation ${ }^{3}$

$$
\sigma_{\mathrm{z}}=\frac{\mathrm{N}_{\mathrm{d}}}{\text { Total Area }} ; \mathrm{V}_{\mathrm{pd}}=\mathrm{N}_{\mathrm{d}}-\sigma_{\mathrm{z}} \times \mathrm{A}_{\mathrm{p}} ; \mathrm{V}_{\mathrm{pr}}=\gamma \times \mathrm{f}_{\mathrm{ctd}} \times \mathrm{u}_{\mathrm{p}} \times \mathrm{d}
$$

\section{THERMAL LAYERS}

Main envelope of the building composes of glass curtain wall. Thanks to structural condition of the building, any type of glass curtain wall should be implemented. Thermal resistance of other components of the envelope structure fulfils the limit conditions (thermal transmittance (U) should be less than $0,5 \mathrm{~m}^{2} \mathrm{~K} / \mathrm{W}$ ) which are as follows: Underground Wall: $3,282 \mathrm{~W} / \mathrm{m}^{2} \mathrm{~K}$; Terrace 1: 3,693 $\mathrm{W} / \mathrm{m}^{2} \mathrm{~K}$; Terrace 1: $3,491 \mathrm{~W} / \mathrm{m}^{2} \mathrm{~K}$; Terrace $3: 3,824 \mathrm{~W} / \mathrm{m}^{2} \mathrm{~K}$; Terrace 4: 4,137 W/m² $\mathrm{K}$.

\section{Final condensation control for all envelope components}

- $\quad$ There is no risk of mould for inner surface since inner surface temperature is under $17^{\circ} \mathrm{C}$.

- Condensation did not occur at building component.

- Condensation investigation of the building element meets the all criteria specified in the standard; therefore it is suitable according to the standard.

\footnotetext{
${ }^{3}$ Explanation for the abbreviations: $\mathbf{V}_{\mathbf{p d}}-$ Design punching force; $\mathbf{V}_{\mathbf{p r}}-$ Resistant punching force; $\boldsymbol{\gamma}-$ Coefficient that reflects bending effect for punching. The value is 1 for axial loading according to TS $500 ; \mathbf{N}_{\mathbf{d}}-$ Transferred design load; $\boldsymbol{\sigma}_{\mathbf{z}}-$ Stress; $\mathbf{f}_{\text {ctd }}-$ Design tensile strength of concrete; $\mathbf{d}-$ Thickness; $\mathbf{A}_{\mathbf{p}}-$ Punching area; $\mathbf{u}_{\mathbf{p}}-$ Punching circle (around half of the thickness added to the column circle).
} 


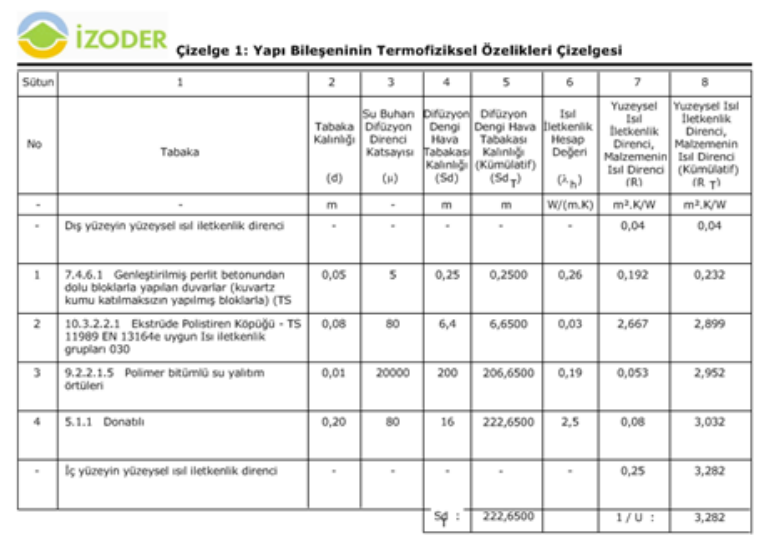

Fig. 3 Detailed properties for the investigated section underground wall

\section{CONCLUSION}

This study provides summarized information for combination of earthquake resistant and sustainable design. The general principle of earthquake resistant design to this specification is to prevent structural and non-structural elements of buildings from any damage in low intensity earthquakes; to limit the damage in structural and non-structural elements to repairable levels in medium intensity earthquakes and to prevent the overall or partial collapse of buildings in high-intensity earthquakes in order to avoid the loss of life. A building which allows high level of interchange ability provides infrastructure for easier future implementations. Classical reinforced concrete structures provide very limited change option for possible innovations in the building. Sometimes, people cut beams or columns which can be reason of fatal mistake. In this sense, the case project has beamless system with long open span (with convenient limits of deflection). This solution is combined with curtain wall system. Therefore, maximum level of solar gain for interior space is intended.

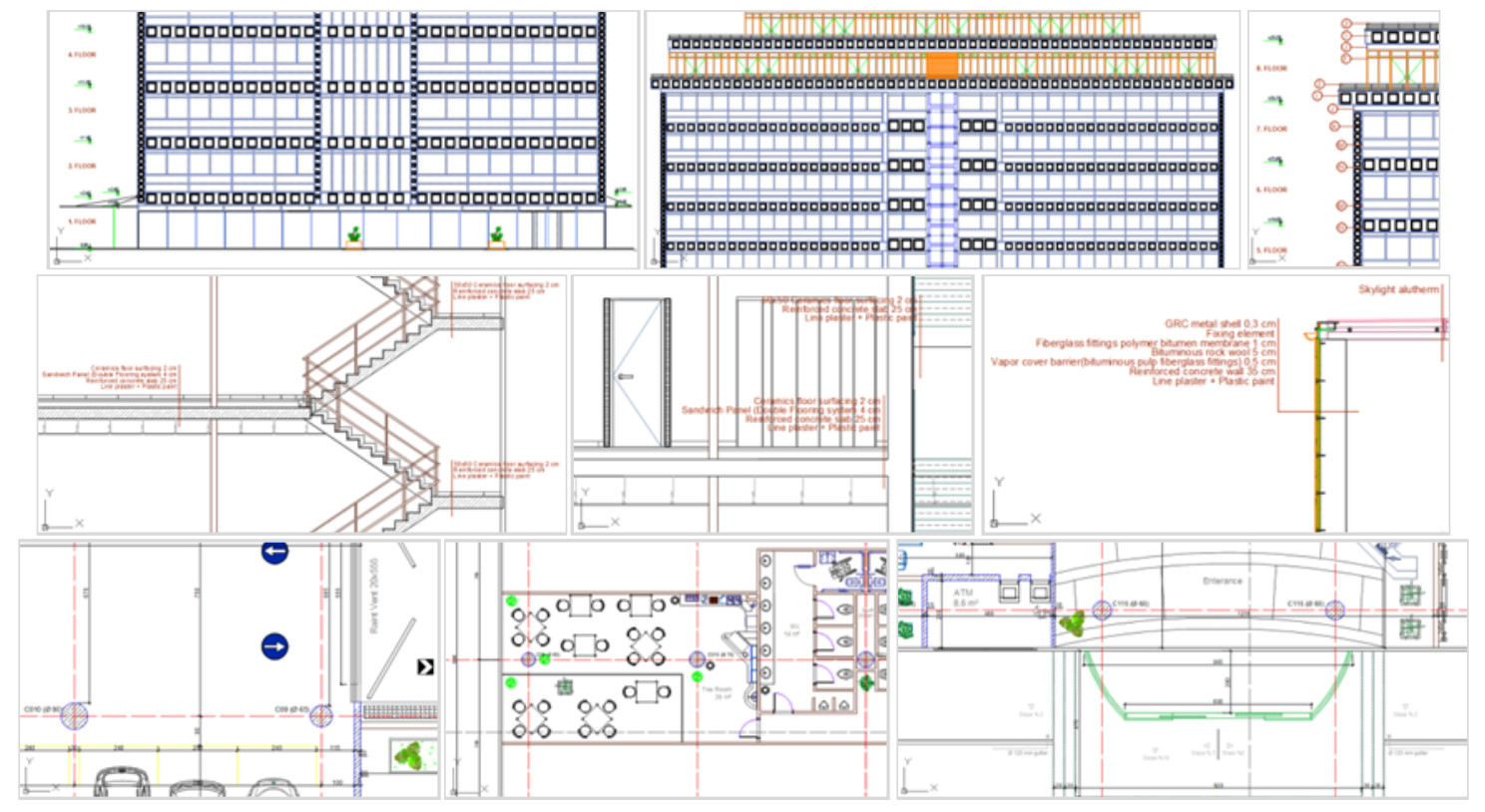

Fig. 4 Parts of drawings from the designed case project

\section{Acknowledgement}

This study avails itself of master thesis with title "Convenient Modern Office Building" of Ing. Kağan Poyraz, Ph.D. with the supervision of Doc.Ing. František Kulhánek, CSc. at Czech Technical University in Prague. 


\section{Literature}

[1] PV Potential Estimation Utility. JOINT RESEARCH CENTRE EUROPEAN COMMISSION. Interactive Maps [online]. 2015 [cit. 2015-02-10]. Dostupné z: http://re.jrc.ec.europa.eu/pvgis/apps4/pvest.php

[2] ASIMGIL, Bedriye. Cam Bina Cephelerinin Optimizasyonunda Sürdürülebilir Mimarliğin Rolü. 2. Ulusal Çatı \& Cephe Kaplamalarında Çă̆daş Malzeme ve Teknolojiler Sempozyumu [online]. 2005 [cit. 2015-08-05]. Dostupné http://www.catider.org.tr/pdf/sempozyum/bildiri_11.pdf

[3] NEUFERT, Peter a Ernst NEUFERT. Neufert Architects' Data. 3. Oxford, United Kingdom: Blackwell Sciences, 2002. ISBN 0632037768.

[4] TS 500. Betonarme Yapılarin Tasartm ve Yapım Kurallarl (Requirements for Design and Construction of Reinforced Concrete Structures). Ankara: Turkish Standards Institute (TSE), 2000.

[5] DBYYHY 2007. Deprem Bölgelerinde Yapılacak Binalar Hakkında Yönetmelik (Regulation of Construction for Buildings in Seismic Zones). Ankara: Union of Chambers of Turkish Engineers and Architects, Civil Engineers Chamber, 2007.

[6] TOPÇU, Ahmet. Betonarme 2. Eskişehir, 2015. Dostupné také z: http://mmf2.ogu.edu.tr/atopcu/index_dosyalar/Dersler/Betonarme2/Sunular/Betonarme_2_2.p df. Lecture. Osmangazi University.

[7] POYRAZ, Kağan. Convenient Modern Office Building. Prague, 2011. Master Thesis. Czech Technical University. Vedoucí práce Doc.Ing. František Kulhánek, CSc.

[8] TS 825. Binalarda Isl Yalitım Kurallarl (Thermal Insulation Requirements for Buildings). Ankara: Turkish Standards Institute (TSE), 2008.

[9] POYRAZ, Kağan. Buildings with Low Energy Consumption for the Republic of Turkey. Prague, 2015. Doctorate Dissertation. Czech Technical University in Prague. Vedoucí práce Doc.Ing. František Kulhánek, CSc. 